\title{
A SIGNIFICAÇÃO DO INGRESSO DO JOGADOR NEYMAR NO BARCELONA FUTEBOL CLUBE: DISCURSO DO ESPORTE ESPETACULAR E DE JOVENS UNIVERSITÁRIOS
}

Francisca Islandia Cardoso da Silva, Fundação Municipal de Saúde de Teresina, Teresina, Piauí - Brasil

\section{RESUMO}

O objetivo deste estudo é investigar como uma reportagem do programa Esporte Espetacular aborda discursivamente o ingresso de Neymar no Barcelona Futebol Clube e o modo de apropriação da mensagem por jovens universitários. Fez-se uso da técnica de grupos focais e do método analítico-descritivo para coleta e análise dos dados. A amostra foi constituída por 24 jovens universitários, na faixa etária entre 18 e 24 anos. Neymar é caracterizado pelo EE como o ídolo que “deixou para trás” um time que não mais era digno de seu talento e alcançou o objetivo de vários jogadores no mundo inteiro, o Barcelona. O discurso do EE está ligado à ideia de que com persistência, disciplina, confiança e talento, Neymar foi capaz de ultrapassar as dificuldades, de se aperfeiçoar, exercer seu imenso potencial e chegar onde desejava, ao Barcelona FC. Segundo os sujeitos da pesquisa, a representatividade de Neymar ocorre em decorrência de, no Brasil, o futebol ser palco profícuo para a construção de imagens esportivas carregadas de alto simbolismo que serve para difundir uma ideia de identidade nacional.

Palavras-Chave: Discurso; Televisão; Neymar; Recepção.

\section{THE MEANING OF ENTERING OF PLAYER NEYMAR IN BARCELONA FOOTBALL CLUB: SPEECH OF ESPORTE ESPETACULAR AND OF YOUNG UNIVERSITY}

\begin{abstract}
The aim of this study is to investigate how a report of the Sports Spectacular program discursively addresses the entry of Neymar at Barcelona Football Club and the ownership mode of message by university students. There was use of the technique of focus groups and analytical-descriptive method in collecting and analyzing data. The sample consisted of 24 university students, aged between 18 and 24 years. Neymar is characterized by EE as an idol that "left behind" a team that was not worthy of his talent and reached Olympus desired by players around the world, the Barcelona. The EE speech is linked to the idea that with persistence, discipline, confidence and talent, Neymar was able to overcome the difficulties, to improve his immense potential and get where desired, the Barcelona FC. According to the research subjects, the representation
\end{abstract}


of Neymar occurs as a result of, in Brazil, the football be fruitful for the construction of images of high symbolism that serves to spread a idea of national identity.

Key-Words: Speech; Television; Neymar; Reception.

\title{
EL SIGNIFICADO DE LA ADMISIÓN DE EL JUGADOR NEYMAR EN BARCELONA CLUB DE FÚTBOL: DISCURSO DE ESPORTE ESPETACULAR Y JOVENES UNIVERSITARIOS.
}

\begin{abstract}
RESUMEN
El objetivo de este estudio es investigar cómo un informe en el programa Deporte Espectacular aborda discursivamente la entrada de Neymar en el Fútbol Club Barcelona y el modo de apropiación de mensajes para los estudiantes universitarios. Hubo uso de la técnica de grupos focales y método analítico-descriptivo para recopilar y analizar datos. La muestra estuvo conformada por 24 estudiantes universitarios, con edades comprendidas entre 18 y 24 años. Neymar se caracteriza por EE como un ídolo que "quede atrás" un equipo que no era digno de su talento y llegó a Olympus deseada por los jugadores de todo el mundo, de Barcelona. El discurso EE está vinculada a la idea de que con la persistencia, disciplina, confianza y talento, Neymar fue capaz de superar las dificultades, para mejorar el ejercicio de su inmenso potencial y llegar a donde desea, el FC Barcelona. De acuerdo a los sujetos de la investigación, la representación de Neymar es debido, en Brasil, el escenario de fútbol sea fructífero para la construcción de los deportes cargada imágenes de alta simbolismo que sirve para difundir una idea de la identidad nacional.
\end{abstract}

Palabras-Clave: Discurso; Televisión; Neymar; Recepción. 


\section{INTRODUÇÃO}

Kellner ${ }^{1: 59}$ lembra que um sistema de poder e privilégio “condiciona nossos prazeres de tal modo que procuramos certos prazeres sancionados socialmente e evitamos outros”. Um dos deleites mais valorizados atualmente é o esporte e seus sentidos de bravura, habilidade, superação e glória. Como parte orgânica da sociedade, o esporte é objeto de transformações históricas e sociais, as quais poderão ser compreendidas quando levar-se em consideração a relação com a falação criada pelos meios de comunicação e as formas como o sistema esportivo negocia com ela.

Segundo Bracht, ${ }^{2}$ como espetáculo, o esporte necessita de consumidores e da mídia para ser reconhecido pelos outros campos sociais. A mídia, através de seu poder de suscitar emoções, trata o esporte a partir de uma estratégia de mitificação, a qual agrega valor narrativo à imagem dos atletas de alto rendimento, físico e financeiro. Além disso, a linguagem midiática pode orientar as ideias do receptor sobre um determinado acontecimento e fazê-lo criar expectativas quanto, por exemplo, a um jogo, um atleta ou uma competição. Nesse cenário de colaboração entre o sistema esportivo e os meios de comunicação, o autor afirma que

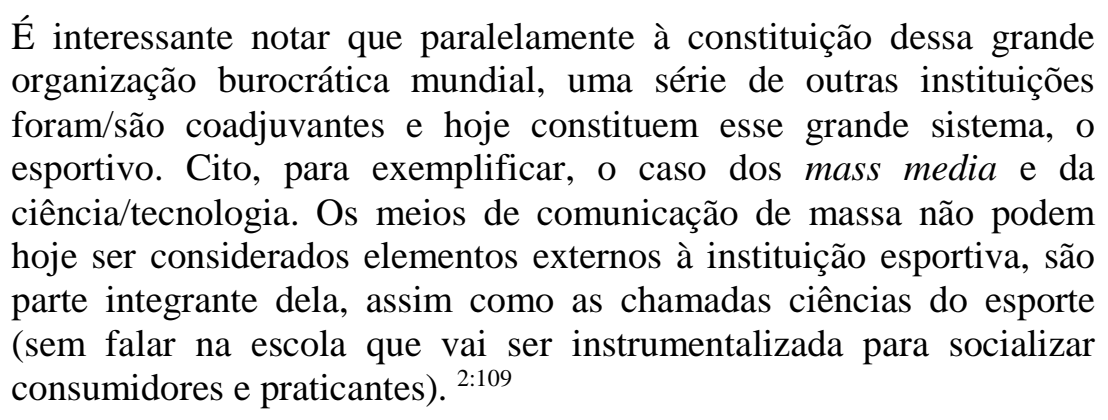

No âmbito do jornalismo, observa-se que a editoria esportiva - seja de jornais, revistas, programas televisivos ou sites - apresenta maior ousadia na linguagem, na escolha das pautas, na expansão de ideias e abordagem de temas distintos que surgem inseparáveis ao esporte ${ }^{3}$. Dentro desse panorama, no Brasil, o futebol espetacularizado é um dos grandes filões dos meios de comunicação e passa a ter caráter dual, pois ao mesmo tempo em está à disposição das lógicas do mercado, não perde sua função como produto sociocultural. Para o antropólogo Roberto DaMatta, ${ }^{4}$ o futebol brasileiro estabelece uma analogia entre o espetáculo midiático e a realidade nacional.

Conexões: revista da Faculdade de Educação Física da UNICAMP, Campinas, v. 13, n. 4, p. 79- 99, out./dez. 2015. ISSN: 1983-9030. 
Assim, embora o futebol seja uma atividade moderna, um espetáculo pago, produzido e realizado por profissionais da indústria cultural, dentro dos mais extremados objetivos capitalistas e burgueses, ele não obstante, também orquestra componentes cívicos básicos, identidades sociais importantes, valores culturais profundos e gostos individuais singulares. ${ }^{4: 12}$

Conforme DaMatta, ${ }^{4}$ a interiorização de atletas pela sociedade evidência a busca desta por sucesso e vitória. Nessa perspectiva, o heroísmo, retratado por Campbell, ${ }^{5}$ fala sobre feitos sobrenaturais cumpridos por seres diferenciados que alcançam o reconhecimento por desempenhar papel importante em um acontecimento ou período histórico local ou internacional.

Em meio aos critérios para a consagração de um grande protagonista contemporâneo, que alie os elevados índices de audiência e uma identificação com os espectadores/consumidores, surge Neymar como uma nova personalidade do universo imaginário dos consumidores da crescente indústria do entretenimento.

As questões que atravessam o estudo são: como é construída a imagem pública de Neymar pelo EE? Como os jovens teresinenses universitários se apropriam do discurso do EE? Os jovens percebem interesses implícitos nos discursos?

O objetivo geral desta pesquisa é investigar como uma reportagem do programa Esporte Espetacular aborda discursivamente o ingresso de Neymar no Barcelona Futebol Clube e o modo de apropriação da mensagem por jovens universitários.

A amostra do estudo foi constituída por 24 jovens universitários na faixa etária entre 18 e 24 anos, de ambos os sexos. Os dados foram colhidos por intermédio de grupos focais, e as entrevistas gravadas e transcritas. Para análise do conteúdo da matéria e das respostas obtidas por meio dos grupos focais utilizou-se o método analítico-descritivo.

Para uma melhor apreciação da peça jornalística e dos dados colhidos nos grupos focais optou-se por apresentá-las separadamente. Inicialmente, são descritas as estratégias desenvolvidas pelo Esporte Espetacular em seu discurso sobre a apresentação oficial de

Conexões: revista da Faculdade de Educação Física da UNICAMP, Campinas, v. 13, n. 4, p. 79- 99, out./dez. 2015. ISSN: 1983-9030. 
Neymar ao Barcelona Futebol Clube. Em seguida, analisa-se a leitura que jovens teresinenses fazem da mensagem da peça.

\section{PROCEDIMENTOS METODOLÓGICOS}

A opção por trabalhar com o programa Esporte Espetacular deu-se em razão deste ser um dos principais telejornais esportivos de transmissão nacional do Brasil e, também, da maior facilidade de acompanhamento das matérias e coleta e registro das informações. A reportagem selecionada, intitulada pelo EE como "Neymar realiza sonho de jogar com a camisa do Barcelona no Camp Nou”, foi exibida em 4 de agosto de 2013 e é marcada pela entonação dramática da voz do narrador, pelo uso de expressões cotidianas e metáforas na construção do relato, pelo efeito de slow motion, closes e replays das imagens de Neymar. Pode-se encontrar também uma edição de imagens em que fatos são exibidos fora de sua ordem cronológica real; edição e mixagem de som com repetição da evocação do nome de Neymar, e; uma trilha sonora musical relacionada a sentimento de vitória.

Para análise do conteúdo da matéria do EE e das respostas obtidas por meio dos grupos focais utilizou-se o método analítico-descritivo, que, segundo Minayo, ${ }^{6}$ é aplicável a estudos que objetivem compreender a dinâmica de um determinado fenômeno através do estudo e avaliação aprofundados de informações disponíveis sobre este e, assim, interpretá-lo e explicar seu contexto e as variáveis envolvidas.

A amostra do estudo foi constituída por 24 jovens universitários na faixa etária entre 18 e 24 anos, de ambos os sexos. A escolha por universitários se deu em decorrência de considerar que a educação pode ampliar a capacidade de pensar e contribuir para a formação de um homem preocupado com a coletividade, apto a levar a efeito ações que possam mudar a sociedade. ${ }^{7}$

A amostra foi constituída conforme o método de conveniência, um dos mais flexíveis métodos de amostragem e, por isso, privado de rigidez estatístico. ${ }^{8}$ Os participantes foram selecionados admitindo-se que pudessem de alguma forma representar a

Conexões: revista da Faculdade de Educação Física da UNICAMP, Campinas, v. 13, n. 4, p. 79- 99, out./dez. 2015. ISSN: 1983-9030. 
população de jovens universitários do curso de Educação Física da Universidade Federal do Piauí.

Considerando as vantagens financeiras e práticas, a pesquisa utilizou como estratégia inicial de recrutamento de participantes convites divulgados em redes sociais. Nos convites foram apresentados os objetivos da pesquisa, metodologia e custos e benefícios relacionados à possível participação. Para tornar maiores as taxas de resposta foram enviados lembretes periódicos, ao longo de um mês, para a participação ou disposição com outros dispositivos, como o Whatsapp. Após o contato virtual e caso o participante aceitasse, agendou-se um contato presencial entre a autora do estudo e os jovens universitários para esclarecimentos sobre a pesquisa e cadastro dos interessados em participar. Logo depois, foram organizados os grupos focais e marcadas as sessões. Para montagem dos grupos focais, além de abarcar os critérios de participação anteriormente expostos, seguiu-se dois critérios: (i) evitou-se alocar em um mesmo grupo pessoas do mesmo círculo imediato de convivência; (ii) apenas estudantes do curso de Educação Física poderiam participar. A exigência do último critério dá-se em decorrência da maior disponibilidade de acesso aos jovens do curso de Educação Física pela autora do estudo em razão da mesma fazer parte do corpo docente do curso de Licenciatura em Educação Física da Universidade Federal do Piauí no período de realização da pesquisa.

Os dados foram colhidos por intermédio de grupos focais, e as entrevistas gravadas e transcritas. Conceitualmente, o grupo focal é uma técnica de entrevista utilizada em pesquisas qualitativas, que tem o propósito de coletar dados através da interação grupal e consiste em uma exposição oral específica dos envolvidos para que o pesquisador possa obter mais respostas através de sondagens sobre as razões ocultas em relação a um determinado comportamento dos participantes. ${ }^{9}$ A interação entre os sujeitos pode suscitar o exame de pensamentos e conhecimentos relacionados aos comportamentos e expressões dos participantes. Ao relacionar discursos de diferentes sujeitos sobre uma mesma realidade, constrói-se a tessitura da vida social em que valores, emoções e atitudes estão inscritos.

Conexões: revista da Faculdade de Educação Física da UNICAMP, Campinas, v. 13, n. 4, p. 79- 99, out./dez. 2015. ISSN: 1983-9030. 
O grupo focal girou em torno da temática da peça jornalística, sem, no entanto, desprezar as informações diversas que por ventura surgissem durante o grupo focal desde que pertinentes ao tema da pesquisa. Na sessão, os participantes assistiram à peça jornalística e a seguir foram solicitados pela mediadora - papel exercido pela autora do presente estudo - a verbalizar suas impressões sobre o que tinham assistido.

A sessão - com duração média de uma hora - foi estruturada através de um roteiro específico composto pelas seguintes questões orientadoras: (i) fatores propiciadores da idolatria ao jogador; (ii) Neymar como representante da identidade nacional brasileira; (iii) Apostas sobre a trajetória de Neymar no Barcelona Futebol Clube; e, (iv) suposta rivalidade entre Neymar e Lionel Messi.

Foram realizados três grupos focais com oito jovens em cada grupo em função da complexidade do tema. Os grupos focais foram compreendidos como contextos únicos por serem constituídos por pessoas diferentes.

Tabela 1 - Características dos sujeitos integrantes dos grupos focais

\begin{tabular}{|c|c|c|c|}
\hline \multirow{2}{*}{ Grupo focal } & \multicolumn{2}{|c|}{ Sexo } & \multirow{2}{*}{$\begin{array}{l}\text { Idade média } \\
\text { (anos) }\end{array}$} \\
\hline & Feminino & Masculino & \\
\hline G1 & $50 \%$ & $50 \%$ & 20,8 \\
\hline G2 & $62,5 \%$ & $37,5 \%$ & 19 \\
\hline G3 & $62,5 \%$ & $37,5 \%$ & 21,5 \\
\hline
\end{tabular}

Conforme as condições apresentadas no Termo de Consentimento Livre e Esclarecido (TCLE) entregue a cada um dos participantes, os mesmos estavam cientes de que as informações por eles concedidas seriam usadas exclusivamente para a pesquisa em questão e que os seus nomes seriam mantidos em sigilo.

O presente estudo foi aprovado pelo Comitê de Ética em Pesquisa da Universidade Federal do Piauí - UFPI sob parecer nº 874.966.

Conexões: revista da Faculdade de Educação Física da UNICAMP, Campinas, v. 13, n. 4, p. 79- 99, out./dez. 2015. ISSN: 1983-9030. 


\section{OS FEITOS DO ÍDOLO NEYMAR SEGUNDO O ESPORTE ESPETACULAR}

A matéria foi exibida em 4 de agosto de 2013 e traz como pauta a primeira atuação de Neymar pelo Barcelona FC em partida contra o Santos, clube anterior do jogador. A reportagem começa com uma provocação a Lionel Messi, considerado melhor jogador do Barcelona e um dos melhores do mundo: "Ei Messi, escuta só o som de um sonho se realizando: Neymar". O discurso do EE pressupõe que o "reinado" de Messi estaria ameaçado com a chegada de Neymar, pois ele teria a missão de "deslumbrar a torcida do Barcelona". Existiria nesse momento, um possível duelo pelo posto de "maioral" do time. De um lado Messi, eleito por quatro vezes seguidas melhor jogador do mundo ao vencer o Prêmio Bola de Ouro FIFA. Do outro lado, Neymar, promissor jogador considerado pelo EE como capaz de subjugar Messi.

Segundo Adorno; Horkheimer, ${ }^{10}$ na indústria cultural a notícia se transforma em produto de consumo com a relevância do departamento comercial na empresa jornalística. Depois que o esporte, principalmente o futebol, foi assimilado pelas massas, ele passou a ser avaliado como espetáculo por meio das imagens veiculadas pela mídia e tornou-se um show de entretenimento. Ao analisar a reportagem do EE, percebe-se o quanto a imagem é controlada por profissionais preocupados em mostrar somente o que lhes interessa como se quisessem manipular a capacidade crítica do telespectador.

Embora o EE afirme apresentar o evento objetivamente ("Ei Messi, escuta só o som de um sonho se realizando”) alegando reproduzir a realidade, ele utiliza artifícios característicos da produção do espetáculo. Não é apenas através do merchandising ou do testemunhal que o jornalismo suporta intervenções. A primeira atuação de Neymar é modificada pelo EE com uma carga elevada de drama na entonação da voz do repórter, música, metáforas na construção do relato ("o som de um sonho se realizando"), tecnologia avançada de câmeras que perseguem o jogador lance a lance, câmera em slow motion na entrada dele em campo, closes do jogador e inúmeros replays do chamado do locutor pelo nome de Neymar.

Conexões: revista da Faculdade de Educação Física da UNICAMP, Campinas, v. 13, n. 4, p. 79- 99, out./dez. 2015. ISSN: 1983-9030. 
No discurso do EE identifica-se claramente a intenção de construir Neymar como ídolo. Observa-se o que Charaudeau ${ }^{11}$ denomina espetacularização do conflito verbal no modo como a apresentação de Neymar é tratada, como se o ocorrido fosse o crivo de interesse de todo o público e devesse se circunscrever na ordem do espaço público como destaque de um programa televisivo com grande audiência. A reportagem parece ter sido construída por um contador de histórias: "Neymar pisou o gramado no Camp Nou e um passo adiante para a história”. Para adornar o imaginário do telespectador e atingir a sua audiência, a reportagem faz uso de estratégias criativas e expressões que podem possibilitar a identificação com o que estão falando: "se a vida era preta e branca, agora ela é azul e grená”. Como em um verdadeiro espetáculo, o EE entrelaça texto verbal e não verbal de tal forma que aumenta enormemente a importância daquele jogo, ou melhor, 'O jogo'.

O interesse do EE em dar visibilidade a Neymar é tal que a cada imagem do jogador exibe-se logo em seguida a euforia da torcida, como se a razão para isso fosse a simples presença de Neymar. Fatos que ocorreram no início do jogo, ou seja, sem a presença de Neymar são expostos como alusivos à idolatria ao jogador. A cada gol feito pelo Barcelona (placar final de 8 a 0 para o time catalão), a torcida explodia em felicidade pela atuação do time, porém esse entusiasmo foi mostrado pelo EE de tal forma que parecia ser destinado especificamente a Neymar. Também o chamado feito pelo locutor pelo nome de Neymar ocorreu somente no segundo tempo, quando o jogador entrou em campo. No entanto, mais uma vez, o EE espetacularizou a notícia e repetiu a invocação por 4 vezes durante a matéria de menos de três minutos.

Observa-se um comportamento de enaltecimento de Neymar por parte do EE em seu primeiro jogo com a nova camisa, era "hora de deslumbrar a torcida do Barcelona”. Porém, essa expectativa foi frustrada pela decisão do técnico Gerardo Martino em não o escalar como jogador titular. Nessas circunstâncias, para manter, mesmo que no discurso, a hegemonia de Neymar e afagar o sentimento de derrota o EE esclarece que Martino é argentino. Não há pelo EE o reconhecimento de um possível equívoco de avaliação sobre Neymar. A reportagem não pontua que por ser estreante, não há ainda

Conexões: revista da Faculdade de Educação Física da UNICAMP, Campinas, v. 13, n. 4, p. 79- 99, out./dez. 2015. ISSN: 1983-9030. 
entre Neymar e o restante do time o entrosamento necessário para um bom desempenho do Barcelona.

O posicionamento do EE reflete a tradicional animosidade existente entre Brasil e Argentina, consequência de comparações entre as identidades culturais e políticas próximas, mas divididas por fronteiras idiossincráticas bem demarcadas. França e Inglaterra, Austrália e Nova Zelândia, Portugal e Espanha, Israel e Palestina, para citar alguns casos bem conhecidos, também mantêm rivalidades alimentadas por processos que incutem no inconsciente coletivo uma relação emocional na qual o vizinho é estigmatizado. Elias; Scotson ${ }^{12}$ afirmam que grupos vizinhos tendem a negar o Outro e estigmatizá-lo com deficiências como reforço para a constituição de valores para a própria identidade e autoestima.

Mesmo após se tornarem aliados comerciais com a fundação do Mercosul em 1990, há de se considerar que desde o século XIX brasileiros e argentinos mantêm com frequência posições antagônicas, notadamente ao digladiarem-se no campo diplomático pela liderança regional. Este estudo não segue a linha frankfurtiana, mas sim a teoria da “ilusão discursiva” de Michel Pêcheux ${ }^{13: 169}$ que visualiza a interferência da mídia como reforço à prevalência desse discurso estigmatizante e sua legitimação pela via de reiterações do imaginário coletivo. Segundo o autor, o jornalismo vive uma espécie de esquecimento e emite conceitos como se fossem próprios, mas, na verdade, o que faz muitas vezes é validar a conceituação definida pela classe dominante a respeito de determinados valores. A menção do EE sobre a nacionalidade de Martino é feita como se fosse um traço universalmente aceito e inquestionável a respeito dos argentinos. Conforme Orozco-Gómez, ${ }^{14}$ essa situação mostra que a TV é, concomitantemente, meio técnico de produção e transmissão de informação, e também, instituição produtora de significados. Essa dualidade da TV lhe confere recursos para aumentar o seu poder legitimador diante da audiência.

Martín-Barbero ${ }^{15}$ chama a atenção para o fato de que um diversificado leque de mediações socioculturais se faz presente no processo de construção de sentidos e valores que desembocam no discurso da mídia. No entanto, mais do que um 
mero suporte técnico repetidor, os meios de comunicação interagem com esse conjunto de mediações balizadas pela ideologia dominante. Dessa forma, cria-se uma roda-viva em que os desejos do establishment delineiam o que é publicado ou transmitido oralmente e, assim, são renovados e reforçados os desejos sociais por meio da imprensa.

A matéria exibe em slow motion o momento em que Neymar executa exercício de aquecimento em frente a uma bandeira do Santos, "símbolo do que Neymar deixou para trás”. O narrador menciona que "se a vida era preto e branco, agora ela é azul e grená” em clara alusão ao novo status de Neymar: jogador do Barcelona FC. O Santos Futebol Clube é mostrado como um time de nível abaixo do catalão, logo, aqueles que alcançarem a chance de chegar ao Barcelona sofrem uma reviravolta em sua vida, uma mudança para melhor. Com isso, Neymar é caracterizado pelo EE, mais uma vez, como ídolo que “deixou para trás” um time que não mais era digno de seu talento e alcançou o objetivo almejado por jogadores do mundo inteiro, o Barcelona.

Vestir a camisa do Barcelona é considerado pelo EE uma responsabilidade enorme, “coisa de gente grande”, ainda mais para um jovem de apenas 22 anos de idade. O discurso do EE está ligado à ideia de que com persistência, disciplina, confiança e talento, Neymar foi capaz de ultrapassar as dificuldades, de se aperfeiçoar, exercer seu imenso potencial e chegar onde desejava, ao Barcelona FC. Através dessa narrativa o jogador é exibido como um menino/homem extraordinário e, ao mesmo tempo, objetiva-se promover uma aproximação entre o ídolo e seus fãs, alimentando nos últimos a ideia de que são tão capazes quanto o primeiro de encarar os próprios fantasmas e não serem apenas coadjuvantes. Para tanto, esses fãs devem duplicar, reproduzir e encontrar sentido na incorporação de Neymar como modelo. Sua personalidade, gostos, carisma e talento seriam o segredo para conquistar seus objetivos.

Neymar é caracterizado pelo EE como “craque” pertencente ao escalão superior dos jogadores de futebol, mas humilde e leal aos amigos ao ser "carinhoso e brincalhão" com o ex-colega de clube, Giba. Destaca-se, contudo, que essas declarações são dispostas pelo EE e não necessariamente equivalem ao posicionamento do público 
quanto ao jogador. Os veículos de comunicação instituem com seu público uma espécie de contrato de leitura, que para Verón ${ }^{16: 236}$ é:

[...] um espaço imaginário onde percursos múltiplos são propostos ao leitor; uma paisagem, de alguma forma, na qual o leitor pode escolher seu caminho com mais ou menos de liberdade, onde há zonas nas quais ele corre o risco de se perder ou, ao contrário, que são perfeitamente sinalizadas. Essa paisagem é mais ou menos plana, mais ou menos acidentada. Ao longo de todo o seu percurso, o leitor reencontra personagens diferentes que lhe propõem atividades diversas e com os quais ele sente mais ou menos desejo de estabelecer uma relação, conforme a imagem que lhe dão, a maneira como o tratam, a distância ou a intimidade que lhe propõem. Um discurso é um espaço habitado, cheio de atores, de cenários e de objetos e ler é 'movimentar' esse universo, aceitando ou rejeitando, indo de preferência para a direita ou para a esquerda, investindo maior ou menor esforço, escutando com um ouvido ou com os dois. Ler é fazer: é preciso, pois, terminar com o procedimento tradicional que se limita a caracterizar o leito 'objetivamente', isto é, passivamente em termos de CSP (categorias socioprofissionais) ou de estilo de vida, sem jamais indagar-se sobre a questão de saber o que ele faz (ou não faz) quando lê.

De qualquer forma, os valores e sentimentos expressos na trajetória de Neymar podem influenciar a experiência dos indivíduos não apenas suscitando manifestações a favor ou contra certos comportamentos, mas também impulsionando ponderações, identificações e projeções em relação à vida desses indivíduos. Verón ${ }^{16}$ observou em capas de revistas esse jogo de linguagem, onde se estruturam relações e certa conivência entre enunciador e destinatário através do discurso. Dentro dessa disposição, o enunciador se dispõe a dialogar com o destinatário.

Há uma dualidade na construção do ídolo, pois ao mesmo tempo em que se buscam deuses terrenos há também a questão de perceber a si mesmo nele, compreendendo que o ídolo é tão humano quanto os mortais que o contemplam. Essa propriedade é visivelmente fortalecida pelas mensagens midiáticas. Exemplo disso é que a reportagem do EE exalta o aspecto mais humano e suscetível de identificação e semelhança de Neymar com o público do programa. No entanto, imediatamente após essa passagem, a reportagem aborda a atuação do jogador durante a partida: "Em campo, dois lances de craque”. Salienta-se, dessa forma, a índole que distingue o ídolo das pessoas comuns. 
A reportagem parece ter sido feita pela assessoria do jogador quando diz "calma Neymar, é só o começo” ao comentar que o jogador não fez nenhum gol na partida contra o Santos e exaltar sua imagem de grandeza e aura de heroísmo. A matéria afirma também que havia "umas 800 câmeras apontadas ali pro Neymar e seus novos colegas de time” e, ao final do jogo, “quando ele ia sair de fininho, um braço impede a caminhada. A primeira entrevista à beira do campo”. Segundo o EE “Neymar ainda vai falar muito em Barcelona e ainda vai dar muito o que falar”. Esse discurso reitera - de forma exagerada - Neymar como um jogador incomum dentro de campo, uma grande marca.

Pode-se verificar a estratégia do EE na imagem em close e slow motion do jogador trabalhado mais uma vez como um guerreiro - duas demarcações subentendidas: o suor escorrendo pela face e o olhar fixo de dever cumprido. A imagem alinha-se ao destaque dado a Neymar como um homem que sempre se superou, lutou bravamente, por isso mesmo merecedor de ser ovacionado e aplaudido (a reportagem mostra a euforia da torcida pela vitória do Barcelona e reprisa, mais uma vez, o chamado do locutor da partida pelo nome de Neymar).

Se Neymar ganha status de “craque” para muitas pessoas e em muitos lugares, pode-se dizer que isto se dá principalmente pelo fato de que "as palavras simples do nosso cotidiano já chegam até nós carregadas de sentidos que não sabemos como se constituíram e que, no entanto, significam em nós e para nós.” ${ }^{17: 20}$ Orlandi $^{17}$ afirma que na atividade da linguagem a transmissão de informações só consegue alcançar sentido pleno quando põe em funcionamento a relação entre os sujeitos receptores e sentidos afetados pela língua e pela história como um evento dentro de um contexto imediato, que leva em consideração também a ideologia de quem emite e recebe os sentidos do texto que está sendo enunciado. Fez-se sentido, naquele momento, e dentro do contexto milionário e de vitórias, que Neymar passasse a ser reconhecido como craque e ídolo.

A escolha da imagem em slow motion revela duas intenções estratégicas: primeira, ressaltar a imagem do ídolo em mais um momento de vitória; segunda, mostrar a Conexões: revista da Faculdade de Educação Física da UNICAMP, Campinas, v. 13, n. 4, p. 79- 99, out./dez. 2015. ISSN: 1983-9030. 
imagem de um ídolo que também sofre, aproximando-se da figura de todo homem comum com seus problemas e sofrimentos e, principalmente, procurando levar o telespectador a identificar-se com ele.

\section{MODOS DE APROPRIAÇÃO DA MATÉRIA POR JOVENS UNIVERSITÁRIOS}

Para Aumont, ${ }^{18}$ o receptor possui papel ativo no processo comunicacional. Atua de forma a se reconhecer onde é representado, assim como é capaz de "restituir as partes omissas ou ocultas de objetos representados, ${ }^{\text {18:87 }}$ projetando uma imagem completa. Essa trama de projeção é o que lhe consente adotar uma relação de intimidade, conservar em contínua construção a percepção que possui, além de ter capacidade de alterá-la quando em contato com as representações e imagens em propagação.

Sobre a peça 3, "Neymar realiza sonho de jogar com a camisa do Barcelona no Camp Nou”, os três grupos concordaram com o EE ao afirmarem que, "de uma maneira geral, Neymar carrega consigo múltiplas representações de brasilidade” pelo seu modo de vida, sua cultura e seus hábitos de consumo. Ainda segundo os sujeitos da pesquisa, a representatividade de Neymar ocorre em decorrência do esporte no Brasil especialmente o futebol - ser palco profícuo para a construção de imagens esportivas carregadas de alto simbolismo que serve para difundir uma certa ideia de identidade nacional.

Segundo o G2, um dos elementos que facilitam a idolatria a Neymar está calcado na condição socioeconômica. Quanto mais baixa sua condição socioeconômica e cultural de origem, maior será a capacidade de um sujeito de ser representativo na esfera pública, por seguir o modelo de superação proposto pela cultura esportiva criada pela indústria midiática.

Assim como milhões de brasileiros, Neymar teve de percorrer um tortuoso caminho até o Camp Nou. As inúmeras dificuldades superadas fazem com que eu reconheça seu valor. (Aluno 1, G2)

Os ídolos emergentes do esporte-espetáculo detêm atributos heroicos, levando a sociedade a projetar neles seus sonhos de redenção. ${ }^{5}$ Para G2 e G3, além de fatores 
socioeconômicos, outra questão que reforça a manutenção da imagem de ídolo de Neymar é sua identificação como sujeito pertencente à nação, respondendo como defensor da mesma. Os sujeitos da pesquisa utilizaram uma linguagem predominantemente bélica para compor seus discursos.

Quando um jogador veste a camisa da seleção brasileira em competições de grande repercussão como a Copa América, Olímpiadas, Copa do Mundo, por exemplo, ele dá visibilidade mundial à sua nação. Ele carrega consigo a carga simbólica do país. (Aluno 4, G2)

Mesmo que ainda não tenha participado de uma Copa, Neymar conseguiu algo que todos os brasileiros consideram uma vitória, inclusive eu: entrar para o seleto time do Barcelona. No Barcelona, ele tem a função de exportar ao restante do mundo parte dessa identidade brasileira e por meio dela buscar algum grau de supremacia sobre as demais nações. E como o nosso jeito de superar os europeus e americanos é através do futebol, ele terá de dar bem mais que o seu melhor. (Aluno 5, G3)

Através destes enunciados vê-se a tentativa de superar os adversários estrangeiros América do Norte e Europa, notadamente - que enfraquecem o desejo brasileiro de desenvolvimento e sustentabilidade de forma mais autônoma. Por meio do esporte, principalmente o futebol, far-se-ia uma guerra simbólica em que o vencedor revelaria sua força e poder de uma nação sobre outra rival. Essa guerra serviria, também, como forma de vingar as derrotas sofridas nos campos social, político e econômico. Através da vitória nos campos de futebol, o Brasil deixaria seu “complexo de vira-latas”, como cunhou Nelson Rodrigues, ${ }^{19}$ para constituir um sentimento de autoafirmação. Essa tarefa seria desempenhada pelos atletas, Neymar nesse caso em específico, que carrega a responsabilidade de conduzir seu time à vitória.

Conforme os sujeitos da pesquisa, por mais que Neymar ainda não tivesse marcado nenhum gol ou ganho um título pelo Barcelona FC, ao estrelar o jogador como protagonista da reportagem, o EE deixou claro que confia no desenvolvimento dele como o próximo grande craque do clube. No entanto, para os participantes essa ascensão talvez não viesse a ocorrer por Neymar estar em um time composto por excelentes jogadores. Essa seria a razão para Neymar permanecer no banco de reservas durante parte do jogo contra o Santos FC.

Conexões: revista da Faculdade de Educação Física da UNICAMP, Campinas, v. 13, n. 4, p. 79- 99, out./dez. 2015. ISSN: 1983-9030. 
A reportagem fala como se fosse obrigatório o Neymar estar em campo. A gente sabe que tem toda uma estratégia. Ele está chegando agora e tem outros jogadores, acredito eu, muito melhores do que ele no time. (Aluno 7, G2)

Tem espaço pro Neymar no Barcelona, mas ele não terá aquela idolatria que tinha aqui no Brasil. É tanto que ele baixou a bola dele. Agora é reserva. (Aluno 6, G3)

Diferente de quando ele jogava aqui no Brasil. Aqui ele levava o Santos nas costas. No Barcelona não é assim. O Barcelona é um time de verdade. O Santos só tinha um craque. O Barcelona tem 20. (Aluno $6, \mathrm{G} 1)$

Quanto à citação do principal jogador argentino, Lionel Messi, os participantes afirmaram que a intenção do EE é alimentar uma rivalidade entre Messi e Neymar.

A questão da comparação ao Messi é para tentar colocar o Neymar um pouco superior. O fato dele ser argentino só piora. O desejo do brasileiro é derrotar um argentino, seja no que for. E essa matéria só alimenta essa disputa. (Aluno 3, G1)

Ainda falta muito pra ele apagar a estrelinha do Messi, porque o Messi é o Messi. (Aluno 8, G2)

A gente tem uma parada de querer comparar o Neymar com o Messi que não tem sentido. Por exemplo, o Messi na idade do Neymar já tinha sido eleito o melhor do mundo três vezes, já tinha ganho duas Champions League, e o Neymar não tem nada disso. Minha gente, como é que a gente tá bajulando um cara que não é nada? Mas, segundo essa reportagem quem é Messi perto de Neymar, né (tom irônico)? Fizeram isso com aquele Paulo Henrique Ganso também, e cadê ele agora? Sumiu. Eles enobrecem um cara que ainda não é nada. (Aluno 1, G3)

Brandão $^{20}$ afirma que quando um atleta está com um grau de ansiedade ótimo, ele se encontra psicologicamente estável. Entretanto, quando seu grau de ansiedade está abaixo ou acima do grau ótimo, surgem reações como medo, pessimismo e negligência reveladas em plano somático por tensões musculares e pouca explosão. Uma integrante do G2 relatou que a reportagem marca um estado de vigília constante a que Neymar está submetido, manipulado pela maquinaria da eficiência.

Não estou defendendo o Neymar, mas essa pressão feita pelo programa para que ele faça logo gols, ganhe títulos e seja o melhor jogador do time, superando o Messi, não é boa para um jogador. Nós, como futuros profissionais de Educação Física, sabemos que a cobrança exagerada e sem fundamento sobre um jogador afeta diretamente seu desempenho em campo. (Aluno 1, G2)

Conexões: revista da Faculdade de Educação Física da UNICAMP, Campinas, v. 13, n. 4, p. 79- 99, out./dez. 2015. ISSN: 1983-9030. 
Segundo os integrantes do G3, com o objetivo de envolver o público, a matéria foi intencionalmente submetida a um tratamento de edição e mixagem do som. É importante considerar que imagem, som e discurso são componentes das narrativas audiovisuais, e o modo como são entrelaçadas pode interferir de forma significativa no resultado final da produção da mensagem e produzir um determinado sentido a ser sugerido ao receptor. O efeito sonoro forneceu ao grupo informações para que este reconhecesse e estabelecesse associações.

Realmente, isso é engraçado. Enquanto vocês falam a única coisa que vem a minha mente é a voz de fundo da matéria dizendo Neymar, Neymar. É capaz da gente assistir essa matéria em casa, desligado do mundo e sair falando Neymar também. No começo eu pensei que fosse a torcida gritando mesmo a toda hora pelo Neymar. Agora que vim notar que era o locutor, que ele só falou uma vez e a matéria que repetiu esse chamado. (Aluno 6, G2)

A entonação do texto oral da matéria sugeriu sentimentos diversos ao G1 confirmando a premissa de Martins ${ }^{21}$ de que esse recurso auxiliar da oralidade tem como objetivo contribuir para o êxito da interação comunicativa. Outro elemento sonoro constituinte da peça e citado pelo grupo foi a trilha musical a qual, segundo os participantes, teve o intuito de incutir sentimentos, aumentar a dramaticidade da voz ou produzir paisagens sonoras - por meio da associação com imagens que fazem parte da memória do telespectador - de forma que a peça sugira determinados sentidos para o telespectador.

Trilha sonora de filme de guerra, onde o soldado sai da trincheira todo ensanguentado e ainda carregando um colega morto nas costas. Com essa música, eu acho que eles querem mesmo é fazer a gente imaginar o Neymar numa batalha. A batalha dele seria se sobressair no Barcelona. (Aluno 5, G1)

\section{CONSIDERAÇÕES FINAIS}

Ao representar os anseios de um grupo, Neymar toma para si mais que um papel de celebridade, tornando-se uma figura heroica - redentor da nação brasileira. A narrativa do EE reinterpreta a clássica estrutura narrativa da jornada do herói, proposta por Joseph Campbell ${ }^{5}$, e coloca o jogador como referencial de projeção, uma vez que foi sujeito a duras provações em diversas circunstâncias e saiu vitorioso em todas elas, seja com um

Conexões: revista da Faculdade de Educação Física da UNICAMP, Campinas, v. 13, n. 4, p. 79- 99, out./dez. 2015. ISSN: 1983-9030. 
belo gol ou com uma declaração ao público. O jogador seria, assim, uma representação do sucesso e da vitória para a sociedade.

A apropriação crítica do discurso midiático é parte de um processo que incita os indivíduos a observarem o processo de seleção de determinada informação, e por que temas são omitidos e outros tratados com mais ênfase nas notícias. O discurso dos sujeitos da pesquisa explicita o protagonismo de matérias como as produzidas pelo EE como principais responsáveis pela representação de Neymar na sociedade. Segundo os jovens, Por meio de discursos verbais e não verbais, o Esporte Espetacular projeta Neymar como astro do espetáculo esportivo em território nacional, tornando-o indivíduo detentor da afeição dos telespectadores.

Neymar não foi reconhecido pelos sujeitos da pesquisa como ídolo, uma vez que para eles o atleta ainda não merece obter tal alcunha. O ídolo Neymar é ícone da redenção do oprimido, pois daria aos excluídos a possibilidade de visualizar perspectivas de mudança da sua condição social.

Outra questão a ser considerada é a carência de grandes ídolos contemporâneos na sociedade brasileira, seja no âmbito esportivo ou não. Mesmo que o futebol brasileiro não possuísse um craque como Neymar, a mídia criaria na imaginação do receptor o nome de outra pessoa. Nesse novo ídolo seriam conjugadas emoções, desejos e sentimentos populares que promovessem a identificação do público.

O estudo feito com o programa Esporte Espetacular foi importante para esclarecer que Neymar é um bom jogador de futebol, porém, é supervalorizado a partir de um interesse do programa: lucrar cada vez mais em cima da identificação dos telespectadores com o jogador. Neymar não é um simples jogador de futebol, mas um atleta que se tornou garoto propaganda de várias marcas globais e cuja imagem tem sido cuidadosamente administrada por uma equipe de assessoria. Vê-se neste caso, a extensão da simbiose entre futebol, mídia e capitalismo.

A análise deste trabalho é decorrente de um estudo com jovens da cidade de Teresina no estado do Piauí e, portanto, tem a limitação de se relacionar especificamente às Conexões: revista da Faculdade de Educação Física da UNICAMP, Campinas, v. 13, n. 4, p. 79- 99, out./dez. 2015. ISSN: 1983-9030. 
características dessa realidade. Estudos posteriores que observem os jovens em distintos contextos socioculturais serão importantes para verificar os resultados aqui apresentados.

A influência da mídia sobre o cotidiano social e a união entre a jornada do herói e o constante processo de midiatização em que se encontra a sociedade contemporânea deverá levantar muitos outros questionamentos e pautar outros tantos estudos acerca da criação e do papel do herói na modernidade, seja no esporte ou em qualquer outro ambiente no qual possa se desenvolver.

Esta pesquisa apresenta-se como tentativa de contribuição nos estudos dentro dessa temática, visto que a figura do ídolo é importante para o desenvolvimento dos sujeitos e construção de suas identidades. As análises aqui apresentadas não devem ser vistas como a conclusão do debate, mas como a possibilidade do desenvolvimento de uma abordagem crítica em relação ao que é ofertado ao público e, consequentemente, de melhorias que podem ter impactos positivos na sociedade como um todo.

\section{REFERÊNCIAS}

${ }^{1}$ KELLNER, D. A cultura da mídia: estudos culturais: identidade e política entre o moderno e o pós-moderno. Bauru: EDUSC, 2001.

${ }^{2}$ BRACHT, V. Sociologia crítica do esporte: uma introdução. 3. ed. Ijuí: Ed. da Unijuí, 2005.

${ }^{3}$ COELHO, P. V. Jornalismo esportivo. 3. ed. São Paulo: Contexto, 2008.

${ }^{4}$ DAMATTA, R. Antropologia do óbvio. Revista USP, São Paulo, p. 10-17. 1994.

${ }^{5}$ CAMPBELL, J. O herói de mil faces. 10. ed. São Paulo: Cultrix, 1997.

Conexões: revista da Faculdade de Educação Física da UNICAMP, Campinas, v. 13, n. 4, p. 79- 99, out./dez. 2015. ISSN: 1983-9030. 
${ }^{6}$ MINAYO, M. C. de S. O desafio do conhecimento: pesquisa qualitativa em saúde. 11. ed. São Paulo: Hucitec, 2008.

${ }^{7}$ VYGOTSKY, L. S. Psicologia pedagógica. 2. ed. São Paulo: Martins Fontes, 2004.

${ }^{8}$ MARCONI, M. A.; LAKATOS, E. M. Técnicas de pesquisa: planejamento e execução de pesquisas, amostragens e técnicas de pesquisa, elaboração análise e interpretação de dados. 7. ed. São Paulo: Atlas, 2009. 277 p.

${ }^{9}$ MUNARETTO, L. F.; CORRÊA, H. L.; CUNHA, J. A. C. Um estudo sobre as características do método Delphi e de grupo focal, como técnicas na obtenção de dados em pesquisas exploratórias. Revista Administração da Universidade Federal de Santa Maria, Santa Maria, v. 6, n. 1, p. 09-24, jan. /mar. 2013.

${ }^{10}$ ADORNO, T. W.; HORKHEIMER, M. Dialética do esclarecimento: fragmentos filosóficos. Rio de Janeiro: Jorge Zahar, 1985.

${ }^{11}$ CHARAUDEAU, P. Discurso das mídias. 2. ed. São Paulo: Contexto, 2010.

${ }^{12}$ ELIAS, N.; SCOTSON, J. L. Os estabelecidos e os outsiders: sociologia das relações de poder a partir de uma pequena comunidade. Rio de Janeiro: Jorge Zahar, 2000.

${ }^{13}$ PÊCHEUX, M. Análise automática do discurso (AAD-69). In: GADET, F.; HAK, T. (Org.). Por uma análise automática do discurso. 3. ed. Campinas: Ed. da Unicamp, 1997. p. 61-162.

${ }^{14}$ OROZCO-GÓMEZ, G. O telespectador frente à televisão: uma exploração do processo de recepção televisiva. Communicare, v. 5, n. 1, p. 27-42. 2005.

${ }^{15}$ MARTÍN-BARBERO, J. Dos meios às mediações: comunicação, cultura e hegemonia. 6. ed. Rio de Janeiro: Ed. UFRJ, 2009.

Conexões: revista da Faculdade de Educação Física da UNICAMP, Campinas, v. 13, n. 4, p. 79- 99, out./dez. 2015. ISSN: 1983-9030. 
${ }^{16}$ VERÓN, E. Fragmentos de um tecido. São Leopoldo: Ed. Da Unisinos, 2004.

${ }^{17}$ ORLANDI, E. P. Análise de discurso: princípios e procedimentos. 3. ed. Campinas: Pontes, 2001.

${ }^{18}$ AUMONT, J. A imagem. 7. ed. Campinas: Papirus, 2002.

${ }^{19}$ RODRIGUES, N. À sombra das chuteiras imortais: crônicas de futebol. São Paulo: Companhia das Letras, 1993.

${ }^{20}$ BRANDÃO, R. M. Psicologia do esporte. In: FERREIRA NETO, A. As ciências do esporte no Brasil. São Paulo: Autores Associados, 1995. p. 133-147.

${ }^{21}$ MARTINS, N. S. Introdução à estilística: a expressividade na língua portuguesa.

3. ed. São Paulo: T. A. Queiroz, 2003.

Recebido em: 20 jun. 2015

Aceito em:16 out. 2015

Contato: islandiacardoso@hotmail.com

Conexões: revista da Faculdade de Educação Física da UNICAMP, Campinas, v. 13, n. 4, p. 79- 99, out./dez. 2015. ISSN: 1983-9030. 